\title{
Sistem Pendukung Keputusan Rekrutmen Anggota KPPS Pemilu dengan Metode Simple Multi Attribute Rating Technique
}

\author{
Veradilla Amalia ${ }^{1}$, Syafi'ul Hamidani ${ }^{2}$ \\ ${ }^{1,2}$ Program Studi Sistem Informasi STMIK Bina Nusantara Jaya Lubuklinggau \\ 1,2 Jl. Yos Sudarso No 97 A Kel Jawa Kanan Kota Lubuklinggau Sumatera Selatan \\ e-mail: ${ }^{1}$ veradillaamalia@stmik-bnj.ac.id, ${ }^{2}$ hamidanipertama@ stmik-bnj.ac.id
}

\begin{abstract}
Abstrak
Pelaksanaan pemilu saat ini dilakukan dengan sistem pemilihan serentak dan merupakan sejarah baru dalam proses demokrasi di Indonesia. KPPS merupakan kelompok penyelenggara pemungutan suara yang berada di garis depan proses pemilihan umum. Saat ini pemilihan anggota KPPS di Kota Lubuklinggau dilakukan oleh PPS melalui koordinasi dengan RT setempat untuk memilih secara langsung anggota KPPS. Hal tersebut menjadi permasalahan yaitu anggota KPPS yang dipilih belum sesuai dengan kriteria. Untuk mengatasi permasalahan tesebut, tentunya dibutuhkan sistem pendukung keputusan dalam melakukan rekrutmen anggota KPPS Pemilu yaitu sistem pendukung keputusan rekrutmen anggota KPPS Pemilu menggunakan metode SMART yang terdiri 4 kriteria yang dihasilkan dari uji validitas kriteria dan 50 alternatif berdasarkan teknik sampling kuota.Tentunya dengan sistem ini diharapkan dapat menjadi solusi dalam menyelesaikan masalah proses rekrutmen anggota KPPS sesuai dengan kriteria yang diamanahkan dalam peraturan komisi pemilihan umum di Indonesia. Adapun Model pengembangan sistem yang digunakan dalam membangun sistem adalah model waterfall. Dengan dibangunnya sistem pendukung keputusan rekrutmen anggota KPPS Pemilu dapat membantu PPS dalam pengambilan keputusan menentukan anggota KPPS yang berkualitas.
\end{abstract}

Kata kunci:KPPS, Pemilu, SPK, SMART

\begin{abstract}
The current election is carried out using a simultaneous electoral system and is a new history in the democratic process in Indonesia. KPPS is a polling group that is at the forefront of the general election process. Currently the election of KPPS members in Lubuklinggau City is carried out by PPS in coordination with the local RT to directly elect KPPS members. This becomes a problem, namely that the elected KPPS members do not match the criteria. To overcome this problem, of course, a decision support system is needed in recruiting Election KPPS members, namely a decision support system for the recruitment of Election KPPS members using the SMART method which consists of 4 criteria resulting from the validity of the criteria and 50 alternatives based on the quota sampling technique. Of course, this system is expected to be a solution in solving the problem of the recruitment process for KPPS members in accordance with the criteria mandated in the general election commission regulations in Indonesia. The system development model used in building the system is the waterfall model. With the construction of a decision support system for the recruitment of members of the Election KPPS, it can assist PPS in making decisions to determine quality KPPS members.
\end{abstract}

Keywords:KPPS, Election, SPK, SMART

\section{Pendahuluan}

Pemilihan umum merupakan agenda rutin pelaksanaan demokrasi 5 tahunan. Indonesia merupakan negara dengan penduduk terbesar yang melaksanakan pesta demokrasi. Pemilu untuk tahun 2019 merupakan sistem pemilu yang dilaksanakan serentak dan menjadi sejarah 
tersediri dalam pelaksanaan pemilu di Indonesia. Tepatnya April 2019 pemilihan umum yang berlangsung merupakan pemilihan presiden, wakil presiden, legislatif dan kepala daerah. Pelaksanaan pemilu yang dilakukan secara serentak tentunya memberikan dampak dari semua aspek, diantaranya memberikan kemudahan bagi pemerintah dalam melaksanakan pemilihan umum yaitu pada efektifitas kerja dan efesiensi anggaran. Namun dalam pelaksanaanya tentunya masih banyak hambatan yang dihadapi dalam proses pemilihan umum secara langsung. Dari hasil wawancara dengan Subbag Umum dan Logistik proses rekrutmen anggota KPPS yang dilakukan PPS Kota Lubuklinggau belum menerapkan metode analisis dalam menetukan anggota KPPS yang sesuai dengan kriteria penyelenggara pemungutan suara yang diamanahkan peraturan komisi pemilihan umum. Saat ini pemilihan anggota KPPS dilakukan oleh PPS dengan berkoordinasi pada RT Setempat dengan cara memilih langsung anggota KPPS untuk memenuhi anggota KPPS disetiap TPS tanpa memperhatikan kriteria-kriteria yang mendukung dalam penyelengaraan pemilu. Hal tersebut menjadi permasalahan yang sangat berdampak pada penyelenggaraan Pemilu yaitu anggota KPPS yang tidak memiliki kemampuan yang disyaratkan, mengakibatkan pada proses perhitungan suara pemilih pada setiap TPS membutuhkan waktu yang cukup lama. Untuk menciptakan pelaksanaan pemilu yang efektif dan efisien tentunya diperlukan anggota kelompok penyelenggara pemungutan suara (KPPS) yang memiliki kemampuan yang sesuai dengan persyaratan yang ditetapkan dalam penyelenggaraan kegiatan pemilu.

Maka dari itu diperlukan sistem pendukung keputusan rekrutmen anggota KPPS Pemilu dengan metode SMART yang bertujuan untuk membantu pihak PPS dalam melakukan rekrutmen anggota KPPS sehingga memperoleh anggota KPPS yang sesuai dengan kebutuhan dalam penyelenggaraan pemilu. Sistem dibangun mulai dari proses pendaftaran calon anggota KPPS menggunakan sistem online melalui proses verifikasi dan validasi data yang di peruntukan pada seleksi administrasi, kemudian calon anggota KPPS yang telah lulus administrasi akan diseleksi dengan menggunakan teknik analisa yaitu menggunakan metode SMART untuk dilakukan proses perangkingan terhadap semua kriteria yang terpenuhi oleh calon anggota KPPS diantaranya dengan menggunakan kriteria berdasarkan uji validitas kriteria yaitu umur, kesehatan, domisili, dan pendidikan.

Sistem pendukung keputusan dengan cara sistematis, diawali dari permasalahan, pengumpulan bukti, menentukan kriteria keputusan dalam memilih alternatif sebagai solusi keputusan [1]. SPK digunakan untuk membantu pengambilan keputusan baik secara semi terstruktur dan tidak terstruktur, dimana tidak diketahui secara pasti bagaimana keputusan seharusnya diambil [2]. Permasalahan dalam penelitian ini termasuk keputusan semi terstruktur dimana SPK digunakan manajer dalam pengambilan keputusan, karena teknologi merupakan bagian terstruktur, sementara manajer adalah bagian tak terstruktur dalam melakukan penilaian dan analisis terhadap pengambilan keputusan semi terstruktur [3], [4], [5], [6].

Dalam penyelesaian permasalahan diperlukan metode SMART. Metode SMART merupakan cara penentuan keputusan multi kriteria [7], [8]. Metode ini memiliki cara kerja yang memiliki nilai dan setiap kriteria memiliki bobot yang menggambarkan seberapa penting nilainya [9]. Metode SMART digunakan karena kesederhanaannya dalam merespon pengambilan baik secara kualitatif maupun kuantitatif dan analisis respon nilai bobot pada setiap kriteria [10]. Transparansi dalam proses analisi memberikan pemahaman masalah dan dapat diterima oleh pengambil keputusan. Skala 0 sampai 1 adalah cara pembobotan yang untuk mengetahui nilai perbandingan pada setiap alterntif [11]. Kesederhanaan metode menjadi salah satu faktor penulis dalam menyelesaikan masalah dalam rekrutmen anggota KPPS.

Pada penelitian terdahulu [12] telah dilakukan penelitian dengan melakukan perbandingan metode SAW dan SMART penerima kartu indonesia pintar (KIP) yaitu berdasarkan hasil pengujian menggunakan order analisis bahwa hasil perangkingan terbaik dalam menentukan peserta penerima KIP adalah dengan menggunakan metode SMART. Pada penelitian [13] menghasilkan sistem pendukung keputusan yang merekomendasi hasil yang terbaik perumahan dalam membeli rumah hunian sesuai dengan kriteria yang digunakan. Dengan adanya sistem ini tentunya dapat membantu pihak penyelenggara pemilu khususnya 
PPS Kota Lubuklinggau dalam proses rekrutmen anggota KPPS dan membantu pihak pimpinan dalam menetapkan kelompok penyelenggara pemungutan suara sesuai dengan kompetensi dan kualifikasi yang dibutuhkan

\section{Metode Penelitian}

\subsection{Metode Penelitian}

Metode penelitian yang digunakan pada sistem pendukung keputusan rekrutmen anggota KPPS Pemilu Kota Lubuklinggau dapat dilihat pada gambar 1.

\subsection{Pengumpulan Data}

Dimana tahap ini dilakukan melalui wawancara terstruktur. Peneliti berkomunikasidengan pihak KPUD Kota Lubuklinggau yaitu Kasubbag Umum dan Logistik yang mengetahui mekanisme seleksi, persyaratan, anggota KPPS, jumlah TPS, kelurahan dan kecamatan yang ada di Kota Lubuklinggau. Selain dengan wawancara, pengumpulan data dilakukan dengan cara mencari literatur yang digunakan untuk mengumpulkan informasi sebagai bahan yang digunakan untuk penelitian, yaitu dengan mencari sumber refrensi yang relevan yang berhubungan dengan metode Simple Multi Attribute Rating Technique (SMART).

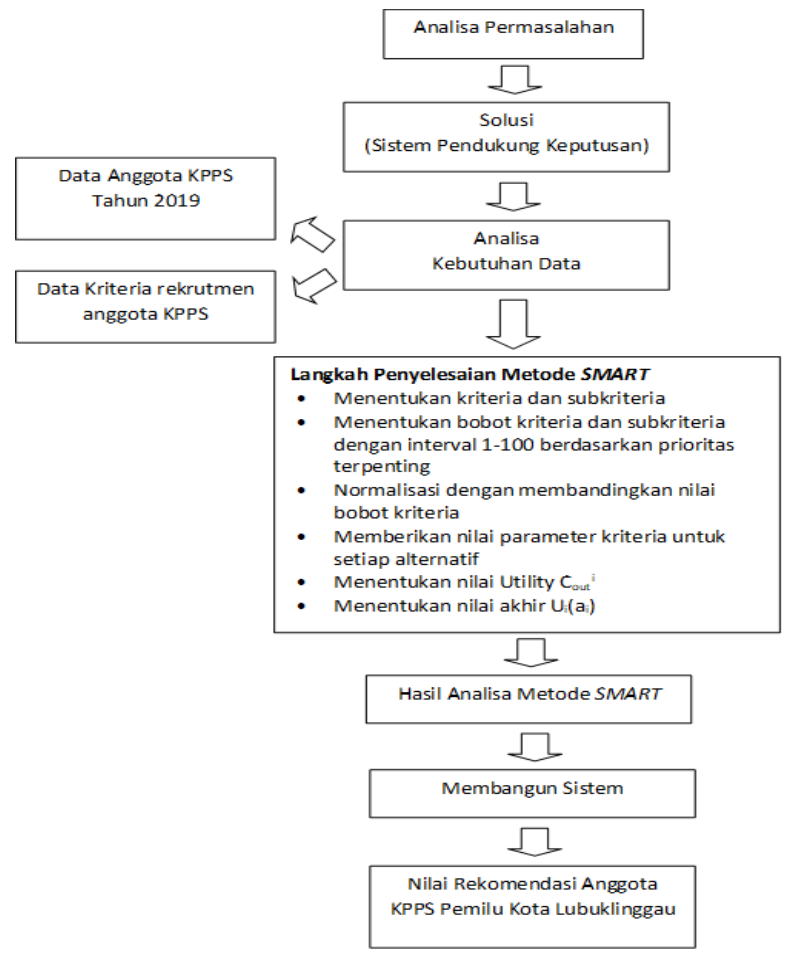

Gambar 1. Tahapan Metode Penelitian

\subsection{Analisis menggunakan metode SMART}

Dari hasil wawancara dan studi pustaka diperoleh ide yang menjadi solusi penyelesaian masalah yaitu membangun sistem pendukung keputusan rekrutmen anggota KPPS Pemilu di Kota Lubuklinggau dengan menerapakan metode SMART.

Adapun tahapan analisis metode SMART sebagai berikut [14].

a. Penentuan kriteria dan alternatif yang akan diterapkan.

b. Menentukan bobot kriteria dengan range 1-100 untuk setiap kriteria berdasarkan prioritas.

c. Melakukan normalisasi kriteria melalui perbandingan nilai bobot kriteria terhadap jumlah bobot kriteria pada suatu skala untuk semua rating alternatif yang tersedia. Dengan persamaan : 


$$
\text { Normalisasi : } \frac{W_{j}}{\sum W_{j}}
$$

Dimana $\mathrm{Wj}$ merupakan nilai bobot kriteria, sedangkan $\sum \mathrm{Wj}$ merupakan total jumlah bobot kriteria.

d. Menentukan parameter dari kriteria untuk setiap alternatif.

e. Menentukan nilai utilitymelalui proses konversi pada setiap kriteria menjadi nilai kriteria yang baku. Nilai utilitydengan persamaan :

$$
U_{i}\left(a_{i}\right)=100 \frac{C_{\max }-C_{\text {out }}}{C_{\max }-C_{\min }} \%
$$

Dimana nilai dari utility kriteria ke-1 digunakan untuk kriteria ke - I, C_max adalah nilai kriteria yang maksimal, merupakan nilai kriteria yang minimal dari nilai kriteria ke- i. Maka didapat nilai tersebut adalah :

$$
C_{\text {out }^{i}}=U_{i}\left(a_{i}\right), I=0 ; 2=0,5: 3=1
$$

f. Menentukan nilai rekomendasi dari hasil perhitungan nilai utility dengan nilai rekomendasi jika >65 Sampai 100 maka nilai rekomendasi lulus seleksi dan jika 0 Sampai 65 maka nilai rekomendasi tidak lulus dilihat dari hasil perhitungan pada setiap alternatif terhadap kriteria yang digunakan.

g. Menentukan nilai akhir dari setiap kriteria dengan cara perkalian nilai yang didapat dari hasil normalisasi nilai kriteria data baku dengan nilai normalisasi bobot kriteria. Lalu ditotalkan dari semua hasil perkalian yang sudah diperoleh.

$$
U_{1}\left(a_{1}\right)=\sum_{j=i}^{m} w_{j} u_{j}\left(a_{i}\right)
$$

Dimana adalah nilai dari alternatif yaitu hasil bobot normalisasi dan hasil penentuan utility.

\subsection{Pengembangan Sistem}

Metode yang digunakan pada pengembangan sistem untuk penelitian ini adalah metode waterfall karena merupakan model dari pengembangan sistem informasi yang sistematik dan sekuensial [15]. Adapun tahapan dalam metode pengembangan sistem yaitu 1). Requirementsanalysis, 2). Desain, 3). Implementation, 4). System testing

\subsection{Pengujian Sistem}

Pengujian Sistem ini merupakan pengujian dari hasil sistem yang dibangun. Adapun teknik yang digunakan untuk melakukan pengujian adalah teknik blackbox testing. Pengujian dilakukan untuk mengetahui fungsi dari setiap halaman sistem yang dibangun apakah berfungsi dan sesuai dengan kebutuhan pengguna.

\section{Hasil dan Pembahasan}

\subsection{Menentukan Kriteria dan Alternatif}

Pemilihan data alternatif merupakan data anggota KPPS pada Kelurahan Watervang Kota Lubuklinggau yang terdiri dari 50 Anggota KPPS seperti pada tabel 1.

Tabel 1. Data Alternatif

\begin{tabular}{lll}
\hline No & Alternatif & Keterangan \\
\hline 1 & Awang & $\mathrm{A}_{1}$ \\
\hline 2 & Romi & $\mathrm{A}_{2}$ \\
\hline 3 & Septy & $\mathrm{A}_{3}$ \\
\hline 4 & Muhammad Sardani & $\mathrm{A}_{4}$ \\
\hline 5 & Maryono & $\mathrm{A}_{5}$ \\
\hline 6 & Seratul & $\mathrm{A}_{6}$ \\
\hline 7 & M. Ferdiansyah & $\mathrm{A}_{7}$ \\
\hline 8 & Suwandi & $\mathrm{A}_{8}$ \\
\hline 9 & Ahmad Abrori & $\mathrm{A}_{9}$ \\
\hline 10 & Jesika Wulandari & $\mathrm{A}_{10}$ \\
\hline
\end{tabular}




\begin{tabular}{lll}
\hline No & Alternatif & Keterangan \\
\hline 11 & Riyanto & $\mathrm{A}_{11}$ \\
\hline 12 & Afif & $\mathrm{A}_{12}$ \\
\hline 13 & Rafael & $\mathrm{A}_{13}$ \\
\hline 14 & Yulius & $\mathrm{A}_{14}$ \\
\hline 15 & Feri & $\mathrm{A}_{15}$ \\
\hline 16 & Handoyo & $\mathrm{A}_{16}$ \\
\hline 17 & Sumarni & $\mathrm{A}_{17}$ \\
\hline 18 & Martini & $\mathrm{A}_{18}$ \\
\hline 19 & Edwin Agus & $\mathrm{A}_{19}$ \\
\hline 20 & Penty & $\mathrm{A}_{20}$ \\
\hline 21 & Monika & $\mathrm{A}_{21}$ \\
\hline 22 & Sarwono & $\mathrm{A}_{22}$ \\
\hline 23 & Lepi harun & $\mathrm{A}_{23}$ \\
\hline 24 & Raden Sudirmo & $\mathrm{A}_{24}$ \\
\hline 25 & Vicnora & $\mathrm{A}_{25}$ \\
\hline 26 & Novan & $\mathrm{A}_{26}$ \\
\hline 27 & Sevitri RW & $\mathrm{A}_{27}$ \\
\hline 28 & Suherdianto & $\mathrm{A}_{28}$ \\
\hline 29 & Ibrahim & $\mathrm{A}_{29}$ \\
\hline 30 & Tubagus S & $\mathrm{A}_{30}$ \\
\hline 31 & Putra Jaya & $\mathrm{A}_{31}$ \\
\hline 32 & Ardiansyah & $\mathrm{A}_{32}$ \\
\hline 33 & Azizah & $\mathrm{A}_{33}$ \\
\hline.. & $\ldots \ldots$ & $\ldots$. \\
\hline 50 & & $\mathrm{~A}_{50}$ \\
\hline & & \\
\hline
\end{tabular}

Data kriteria yang digunakan adalah data kriteria yang diperoleh dari uji validitas kuisioner berdasarkan sebaran kuisioner kepada responden yaitu panitia pemungutan suara. Peneliti menggunakan sample 40 responden dari Kecamatan Lubuklinggau Timur I yaitu penilaian rekrutmen anggota KPPS Pemilu Kota Lubuklinggau yang perlu dilakukan uji validitas terhadap kriteria dengan persamaan ke 4 sebagai berikut [16] :

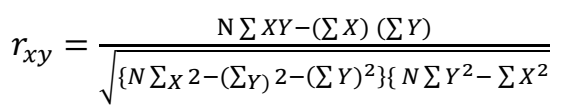

Keterangan :

$\mathrm{X}=$ Hasil kuisioner pertanyaan ke-i

$\mathrm{Y}=$ jumlah keseluruhan dari kuisioner

Dalam penelitian ini uji validitas terhadap criteria menghasilkan nilai signifikasi dengan membandingkan nilai $r$ hitung dengan $r$ tabel untuk degree of freedom dengan alfa $5 \%$ maka di dapatkan $r$ tabel $=0,312$.

Tabel 2. Perhitungan Uji Validitas Kriteria

\begin{tabular}{lllllllll}
\hline \multirow{2}{*}{ Responden } & \multicolumn{9}{c}{ Jawaban Pertanyaan Ke- } & \multicolumn{2}{c}{ Total } \\
\cline { 2 - 8 } & $\mathbf{K}_{\mathbf{1}}$ & $\mathbf{K}_{\mathbf{2}}$ & $\mathbf{K}_{\mathbf{3}}$ & $\mathbf{K}_{\mathbf{4}}$ & $\mathbf{K}_{\mathbf{5}}$ & $\mathbf{K}_{\mathbf{6}}$ & $\mathbf{K}_{\mathbf{7}}$ & \\
\hline $\mathbf{R}_{\mathbf{1}}$ & 4 & 4 & 4 & 4 & 4 & 4 & 4 & 28 \\
\hline $\mathbf{R}_{\mathbf{2}}$ & 4 & 4 & 4 & 4 & 4 & 4 & 4 & 28 \\
\hline $\mathbf{R}_{\mathbf{3}}$ & 3 & 2 & 3 & 4 & 4 & 5 & 5 & 26 \\
\hline $\mathbf{R}_{\mathbf{4}}$ & 4 & 2 & 4 & 4 & 3 & 4 & 4 & 25 \\
\hline
\end{tabular}




\begin{tabular}{|c|c|c|c|c|c|c|c|c|}
\hline \multirow[t]{2}{*}{ Responden } & \multicolumn{7}{|c|}{ Jawaban Pertanyaan Ke- } & \multirow[t]{2}{*}{ Total } \\
\hline & $K_{1}$ & $\mathbf{K}_{2}$ & $\mathbf{K}_{\mathbf{3}}$ & $\mathbf{K}_{4}$ & $K_{5}$ & $K_{6}$ & $\mathbf{K}_{7}$ & \\
\hline $\mathbf{R}_{5}$ & 4 & 2 & 4 & 5 & 5 & 5 & 5 & 30 \\
\hline $\mathbf{R}_{6}$ & 5 & 5 & 4 & 4 & 3 & 5 & 4 & 30 \\
\hline $\mathbf{R}_{7}$ & 5 & 5 & 5 & 4 & 1 & 4 & 1 & 25 \\
\hline $\mathbf{R}_{8}$ & 4 & 4 & 4 & 5 & 5 & 5 & 4 & 31 \\
\hline $\mathbf{R}_{9}$ & 5 & 5 & 5 & 5 & 5 & 5 & 4 & 34 \\
\hline $\mathbf{R}_{10}$ & 4 & 4 & 3 & 4 & 4 & 4 & 4 & 27 \\
\hline $\mathbf{R}$. & $\ldots$ & $\ldots$ & $\ldots$ & $\ldots$ & $\ldots$ & $\ldots$ & $\ldots$ & $\ldots$ \\
\hline $\mathbf{R}_{40}$ & 4 & 3 & 5 & 4 & 4 & 4 & 4 & 28 \\
\hline $\mathbf{R}_{\mathrm{h}}$ & 0,224 & 0,309 & 0,295 & 0,781 & 0,721 & 0,625 & 0,475 & \\
\hline $\mathbf{R}_{\mathrm{t}}$ & 0,312 & 0,312 & 0,312 & $\mathbf{0 , 3 1 2}$ & $\mathbf{0 , 3 1 2}$ & 0,312 & 0,312 & \\
\hline Keterangan & $\begin{array}{l}\text { Tidak } \\
\text { Valid }\end{array}$ & $\begin{array}{l}\text { Tidak } \\
\text { Valid }\end{array}$ & $\begin{array}{l}\text { Tidak } \\
\text { Valid }\end{array}$ & Valid & Valid & Valid & Valid & \\
\hline
\end{tabular}

Keterangan :

$\mathrm{K}_{1}=$ Keanggotaan KPPS 2 Periode, $\mathrm{K}_{2}=$ Memiliki SKCK, $\mathrm{K}_{3}=$ Surat Keterangan Bebas Narkoba, $\mathrm{K}_{4}=$ Pendidikan, $\mathrm{K}_{5}=$ Kesehatan, $\mathrm{K}_{6}=$ Domisili, $\mathrm{K}_{7}=$ Umur

Dilihat dari hasil perhitungan pada tabel 2 dapat disimpulkan kriteria yang dinyatakan valid berdasarkan uji validasi kriteria penilaian dari responden adalah pendidikan, kesehatan, domisili, usia sehingga dapat digunakan sebagai kriteria dalam penelitian ini. Sedangkan penentuan bobot pada setiap kriteria dilakukan berdasarkan hasil wawancara dengan subbag umum dan logistik KPUD Kota Lubuklinggau seperti pada tabel 3 sebagai berikut.

Tabel 3. Data Kriteria dan bobot kriteria

\begin{tabular}{llll}
\hline No & Kriteria & Bobot & Normalisasi Bobot \\
\hline $\mathbf{1}$ & Pendidikan & $20 \%$ & 0.20 \\
\hline $\mathbf{2}$ & Kesehatan & $35 \%$ & 0.35 \\
\hline $\mathbf{3}$ & Domisili & $25 \%$ & 0.35 \\
\hline $\mathbf{4}$ & Umur & $20 \%$ & 0.20 \\
\hline
\end{tabular}

\subsection{Menentukan Nilai Utility untuk Setiap Alternatif}

Dalam proses penentuan nilai utility dengan menggunakan persamaan rumus ke 2, dimana di lakukan proses penginputan atau memasukan nilai pada kriteria untuk dilakukan proses penentuan nilai utility pada setiap kriteria seperti pada tabel 4.

Tabel 4. Tabel Utility

\begin{tabular}{llll}
\hline No & Kriteria & Subkriteria & Input $\mathbf{C}_{\mathbf{o u n}} \mathbf{i}^{\mathbf{i}}$ \\
\hline $\mathbf{1}$ & $\mathbf{C}_{\mathbf{1}}$ & -Pendidikan SMA & 1 \\
& & -Pendidikan D-III & 3.2 \\
& & -Pendidikan S-1 & 5.5 \\
& & -Pendidikan S-2 & 7.75 \\
\hline $\mathbf{2}$ & $\mathbf{C}_{\mathbf{2}}$ & -Surat Keterangan dari Rumah & sakit terakreditasi \\
& & -Surat Keterangan dari Dokter & 1 \\
& & -Surat Keterangan dari Puskesmas & 4.6 \\
& & & 7.75 \\
\hline $\mathbf{3}$ & $\mathbf{C}_{\mathbf{3}}$ & -Memiliki KTP sesuai Domisili & 1 \\
& & -Memiliki KTP tidak Sesuai domisili & 4.6 \\
& & -Surat Keterangan & 7.75 \\
\hline $\mathbf{4}$ & $\mathbf{C}_{\mathbf{4}}$ & -Usia 17 s/d 25 tahun & 1 \\
& & -Usia 26 s/d 40 tahun & 4.6 \\
& & -Usia $>$ 41 Tahun & 7.75 \\
\hline
\end{tabular}




\subsection{Hasil Nilai Utility}

Tahapan ini dilakukan penetapan nilai $\mathrm{C}_{\max }$ dan $\mathrm{C}_{\min }$. yang dapat diketahui melalui nilai input Cout $_{\mathrm{i}}$ yaitu nilai terbesar 10 dan terkecil 1 . Maka hasil nilai utility dapat diperoleh melalui persamaan ke 2 dengan hasil sebagai berikut :

Kriteria Pendidikan $\left(\mathrm{C}_{1}\right)$

subkriteria pend $S M A=100 \frac{10-1}{10-1} \%=100$

subkriteria Pend. $D-3=100 \frac{10-3.2}{10-1} \%=75$

subkriteria Pend $S-1=100 \frac{10-5.5}{10-1} \%=50$

subkriteria Pend. $S-2=100 \frac{10-7.75}{10-1} \%=25$

Kriteria Kesehatan $\left(\mathrm{C}_{2}\right)$

subkriteria Ket RS Akreditasi $=100 \frac{10-1}{10-1} \%=100$

subkriteria ket Dokter $=100 \frac{10-4.6}{10-1} \%=60$

subkriteria ket Puskesmas $=100 \frac{10-7.75}{10-1} \%=25$

Kriteria Domisili $\left(\mathrm{C}_{3}\right)$

subkriteria KTP Sesuai Domisili $=100 \frac{10-1}{10-1} \%=100$

subkriteria KTP non Domisili $=100 \frac{10-4.6}{10-1} \%=60$

subkriteria Surat Keterangan $=100 \frac{10-7.75}{10-1} \%=25$

Kriteria Usia $\left(\mathrm{C}_{4}\right)$

subkriteria usia $17-35$ Tahun $=100 \frac{10-1}{10-1} \%=100$

subkriteria usia $36-45$ Tahun $=100 \frac{10-4.6}{10-1} \%=60$

subkriteria usia $>46=100 \frac{10-7.75}{10-1} \%=25$

Nilai rekomendasi adalah yang digunakan pada metode SMART dalam rekrutmen anggota KPPS Pemilu Kota Lubuklinggau seperti pada tabel 4 dimana range nilai rekomendasi diperoleh berdasarkan wawancara dengan Subbag Umum dan Logistik KPUD Kota Lubuklinggau adapun nilai rekomendasi yaitu $>65$ sampai 100 dinyatakan lulus seleksi dan 0 sampai 65 dinyatakan tidak lulus seleksi.

\subsection{Hasil Perhitungan}

perhitungan dilakukan menggunakan data calon anggota KPPS Tahun 2019 pada Kelurahan Watervang Kota Lubuklinggau pada tabel 5 menggunakan persamaan ke 3 diperoleh hasil perhitungan menggunakan metode SMART yaitu dari 50 anggota KPPS yang dinyatakan lulus seleksi sebanyak 38 orang dan yang dinyatakan tidak lulus seleksi sebanyak 12 orang. 
Tabel 5. Hasil Perhitungan Seleksi Anggota KPPS

\begin{tabular}{|c|c|c|c|c|c|c|c|}
\hline No & Alternatif /Kriteria & $\mathbf{C}_{1}$ & $\mathrm{C}_{2}$ & $\mathbf{C}_{3}$ & $\mathrm{C}_{4}$ & Hasil & Ket \\
\hline- & Bobot & 0,20 & 0,35 & 0,35 & 0,20 & - & - \\
\hline 1 & $\mathbf{A}_{1}$ & 10,00 & 21,00 & 15,00 & 20,00 & 66,00 & Lulus Seleksi \\
\hline 2 & $\mathbf{A}_{2}$ & 15,00 & 35,00 & 25,00 & 20,00 & 95,00 & Lulus Seleksi \\
\hline 3 & $\mathbf{A}_{3}$ & 10,00 & 35,00 & 15,00 & 12,00 & 72,00 & Lulus Seleksi \\
\hline 4 & $\mathbf{A}_{4}$ & 10,00 & 21,00 & 25,00 & 12,00 & 68,00 & Lulus Seleksi \\
\hline 5 & $\mathbf{A}_{5}$ & 20,00 & 0,39 & 25,00 & 12,00 & 65.75 & Lulus Seleksi \\
\hline 6 & $\mathbf{A}_{6}$ & 10,00 & 35,00 & 6,25 & 5,00 & 56,25 & Tidak Lulus \\
\hline 7 & $\mathbf{A}_{7}$ & 15,00 & 21,00 & 15,00 & 12,00 & 63,00 & Tidak Lulus \\
\hline 8 & $\mathbf{A}_{8}$ & 5,00 & 35,00 & 25,00 & 12,00 & 77,00 & Lulus Seleksi \\
\hline 9 & $\mathbf{A}_{9}$ & 5,00 & 21,00 & 15,00 & 12,00 & 53,00 & Tidak Lulus \\
\hline 10 & $\mathbf{A}_{10}$ & 20,00 & 35,00 & 25,00 & 12,00 & 92,00 & Lulus Seleksi \\
\hline 11 & $\mathbf{A}_{11}$ & 15,00 & 21,00 & 25,00 & 20,00 & 81,00 & Lulus Seleksi \\
\hline 12 & $\mathbf{A}_{12}$ & 20,00 & 0,39 & 15,00 & 12,00 & 55.75 & Tidak Lulus \\
\hline 13 & $\mathbf{A}_{13}$ & 10,00 & 21,00 & 25,00 & 20,00 & 76,00 & Lulus Seleksi \\
\hline 14 & $\mathbf{A}_{14}$ & 10,00 & 21,00 & 15,00 & 12,00 & 58,00 & Tidak Lulus \\
\hline 15 & $A_{15}$ & 10,00 & 35,00 & 6,25 & 5,00 & 56,25 & Tidak Lulus \\
\hline 16 & $\mathbf{A}_{16}$ & 10,00 & 21,00 & 15,00 & 5,00 & 51,00 & Tidak Lulus \\
\hline 17 & $\mathbf{A}_{17}$ & 5,00 & 35,00 & 25,00 & 12,00 & 77,00 & Lulus Seleksi \\
\hline 18 & $\mathbf{A}_{18}$ & 15,00 & 35,00 & 25,00 & 12,00 & 87,00 & Lulus Seleksi \\
\hline 19 & $\mathbf{A}_{19}$ & 20,00 & 21,00 & 25,00 & 12,00 & 78,00 & Lulus Seleksi \\
\hline 20 & $\mathbf{A}_{20}$ & 10,00 & 35,00 & 6,25 & 5,00 & 56,25 & Tidak Lulus \\
\hline 21 & $\mathbf{A}_{21}$ & 20,00 & 35,00 & 6,25 & 12,00 & 73,06 & Lulus Seleksi \\
\hline 22 & $\mathbf{A}_{22}$ & 10,00 & 21,00 & 25,00 & 12,00 & 68,00 & Lulus Seleksi \\
\hline 23 & $\mathbf{A}_{23}$ & 10,00 & 21,00 & 15,00 & 20,00 & 66,00 & Lulus Seleksi \\
\hline 24 & $\mathbf{A}_{24}$ & 5,00 & 35,00 & 25,00 & 12,00 & 77,00 & Lulus Seleksi \\
\hline 25 & $\mathbf{A}_{25}$ & 10,00 & 35,00 & 15,00 & 20,00 & 80,00 & Lulus Seleksi \\
\hline 26 & $\mathbf{A}_{26}$ & 20,00 & 0,39 & 25,00 & 12,00 & 65.75 & Lulus Seleksi \\
\hline 27 & $\mathbf{A}_{27}$ & 15,00 & 21,00 & 25,00 & 20,00 & 81,00 & Lulus Seleksi \\
\hline 28 & $\mathbf{A}_{28}$ & 15,00 & 35,00 & 25,00 & 20,00 & 95,00 & Lulus Seleksi \\
\hline 29 & $\mathbf{A}_{20}$ & 15,00 & 21,00 & 15,00 & 12,00 & 63,00 & Tidak Lulus \\
\hline 30 & $\mathbf{A}_{30}$ & 10,00 & 35,00 & 25,00 & 12,00 & 82,00 & Lulus Seleksi \\
\hline 31 & $\mathbf{A}_{31}$ & 15,00 & 21,00 & 25,00 & 12,00 & 73,00 & Lulus Seleksi \\
\hline 32 & $\mathbf{A}_{32}$ & 10,00 & 21,00 & 25,00 & 12,00 & 68,00 & Lulus Seleksi \\
\hline 33 & $\mathbf{A}_{33}$ & 10,00 & 35,00 & 15,00 & 12,00 & 72,00 & Lulus Seleksi \\
\hline .. & .. & & & & & & \\
\hline 50 & $\mathbf{A}_{50}$ & 10,00 & 21,00 & 15,00 & 5,00 & 51,00 & Tidak Lulus \\
\hline
\end{tabular}

\subsection{Pengembangan Sistem}

\section{A. Arsitektur Sistem}

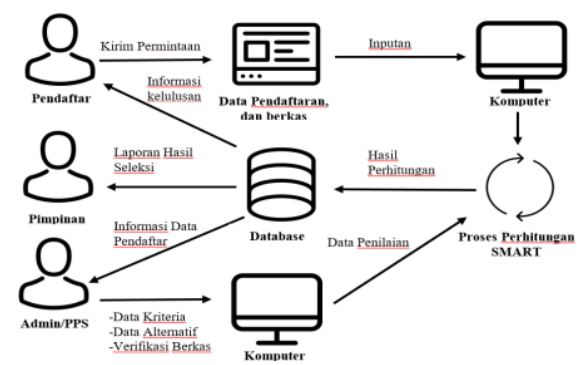

Gambar 2. Arsitektur Sistem 
Gambar 2 merupakan aritektur sistem sebagai aktivitas yang dilakukan pada sistem pendukung keputusan rekrutmen anggota KPPS pemilu Kota Lubuklinggau. Dimana pada sistem ini peserta dapat melakukan pendaftaran anggota KPPS untuk memperoleh akun, kemudian peserta dapat melakukan login untuk mengupload berkas persyaratan seleksi anggota KPPS PEMILU. Admin dapat melakukan proses pengolahan data kriteria, subkriteria, proses verifikasi berkas, proses perangkingan dan hasil perangkingan. Selain itu peserta dapat mengetahui informasi kelulusan administrasi berkas dan kelulusan hasil seleksi rekrutmen anggota KPPS.

\section{B. Perancangan sistem}

Tahap perancangan menggunakan model perancangan UML seperti pada gambar 3. Use case diagram pada sistem rekrutmen anggota KPPS memiliki 3 Pengguna yaitu calon aggota KPPS, administrator/PPS, Pimpinan KPUD Kota Lubuklinggau. Ketiga pengguna tersebut memiliki peran yang berbeda. Dalam hal ini administrator merupakan pengguna tertinggi dalam sistem ini karena mampu mengelola semua aktivitas yang ada pada sistem

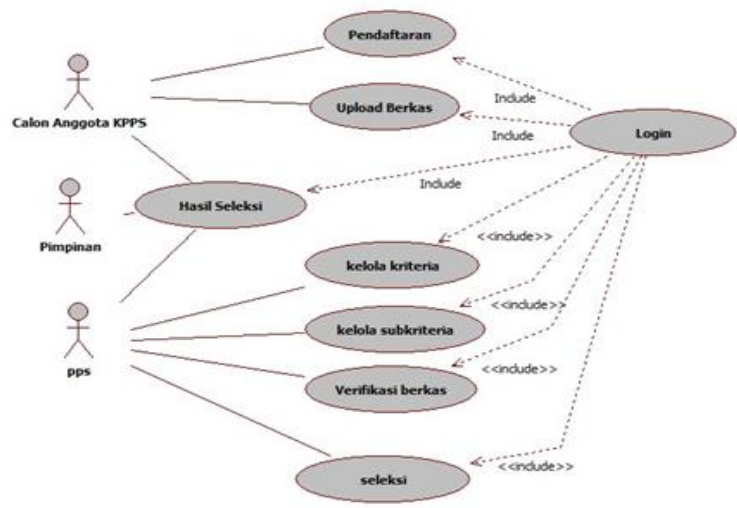

Gambar 3. Use Case Diagram Pengguna

C. Implementasi Sistem

Pada tahap implementasi dihasilkan sebuah sistem rekrutmen anggota KPPS Pemilu Kota Lubuklinggau. Adapun hasil pengembangan sistem menggunakan pemrograman php dan database Mysql dapat seperti yang dijelaskan pada gambar 4 sampai dengan gambar 8 sebagai berikut ;

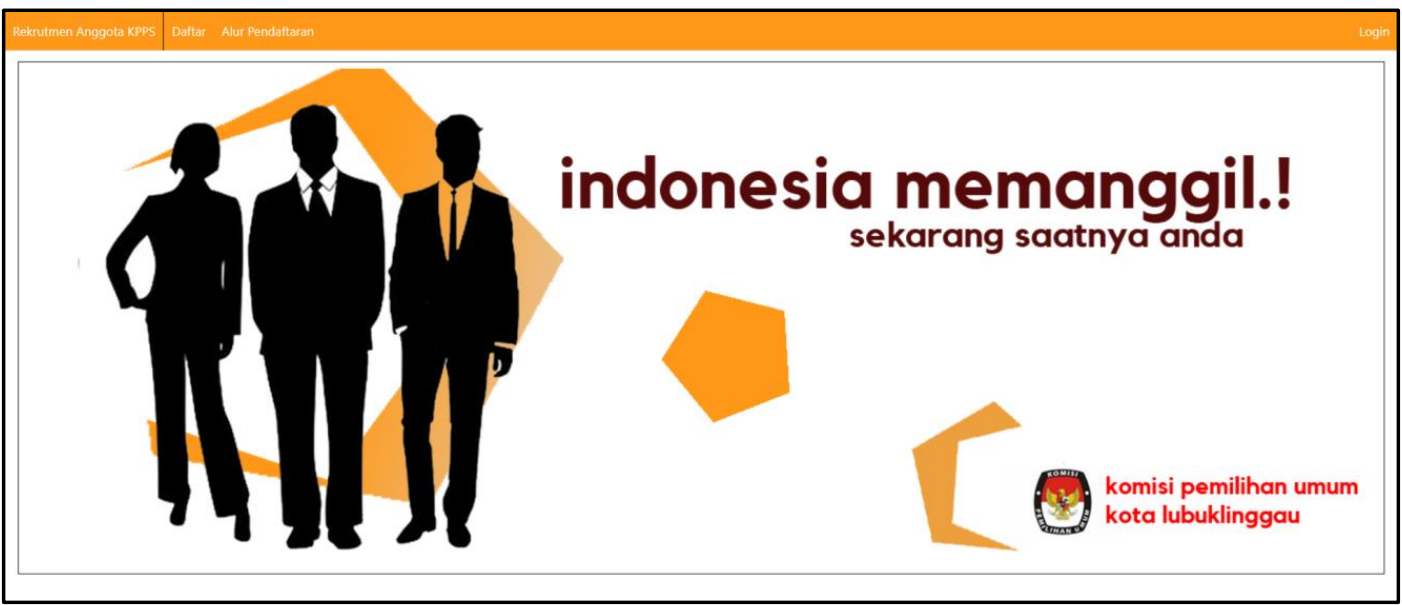

Gambar 4. Halaman Utama Aplikasi

Halaman utama pada aplikasi rekrutmen anggota KPPS Pemilu Kota Lubuklinggau. Dimana halaman utama ini menyediakan menu pendaftaran, alur pendaftaran dan login pengguna baik administrator maupun pendaftar atau calon anggota KPPS Pemilu. 


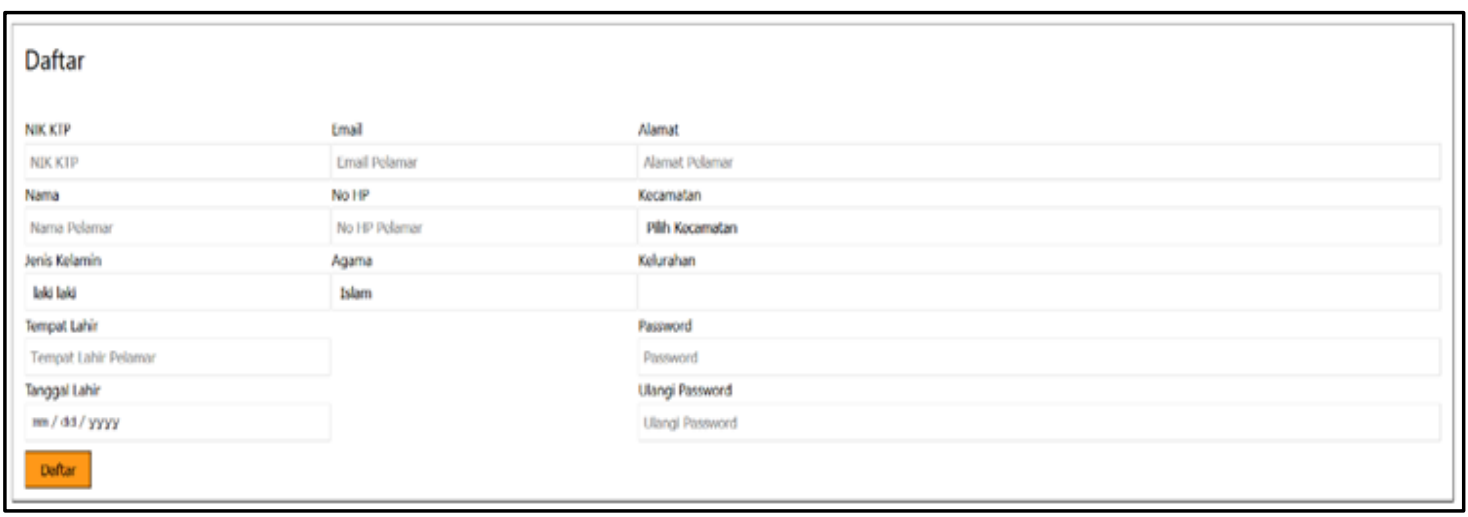

Gambar 5. Halaman Pendaftaran Calon Anggota KPPS

Gambar 5 merupakan halaman antarmuka pendaftaran dimana calon anggota KPPS dapat melakukan pendaftaran dengan mengisi biodata pendaftaran untuk memperoleh akun agar dapat melakukan proses login pada sistem rekrutmen anggota KPPS Pemilu Kota Lubuklinggau.

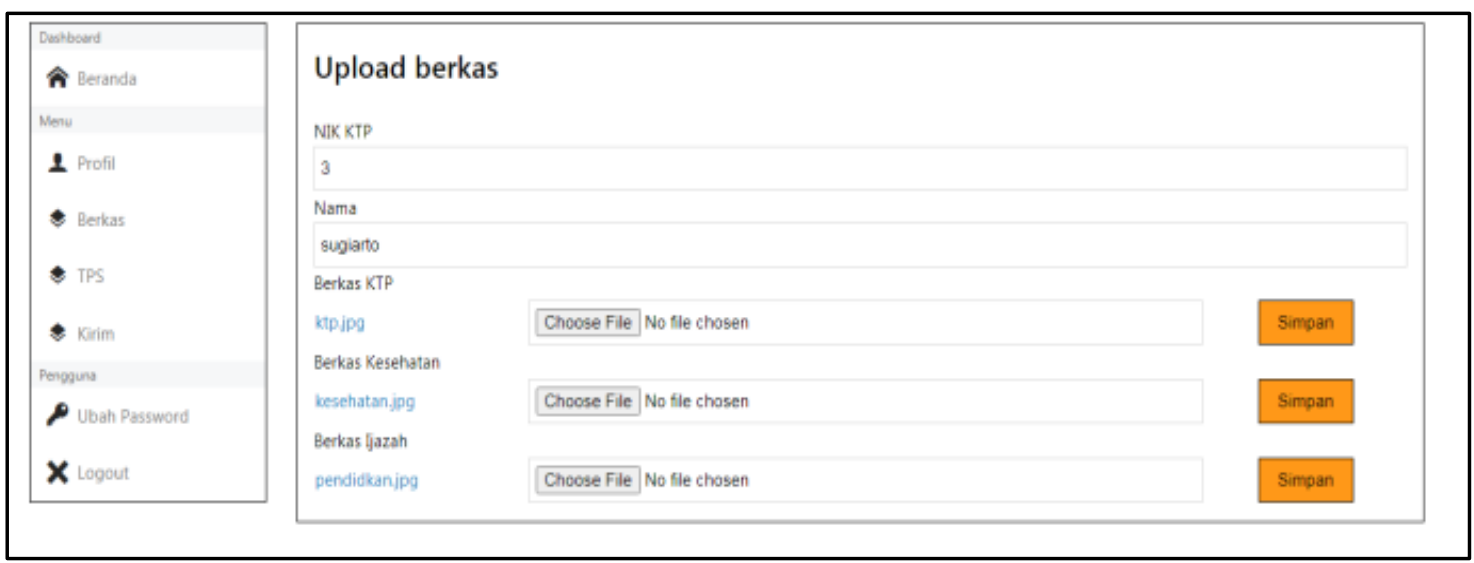

Gambar 6. Halaman Upload Berkas Pendaftaran

Gambar 6 merupakan halaman proses upload berkas yang dilakukan oleh pendaftar sebagai calon anggota KPPS dengan melengkapi persyaratan seleksi anggota KPPS sesuai dengan kriteria yang telah ditetapkan yaitu pendidikan, kesehatan, domisili dan usia.

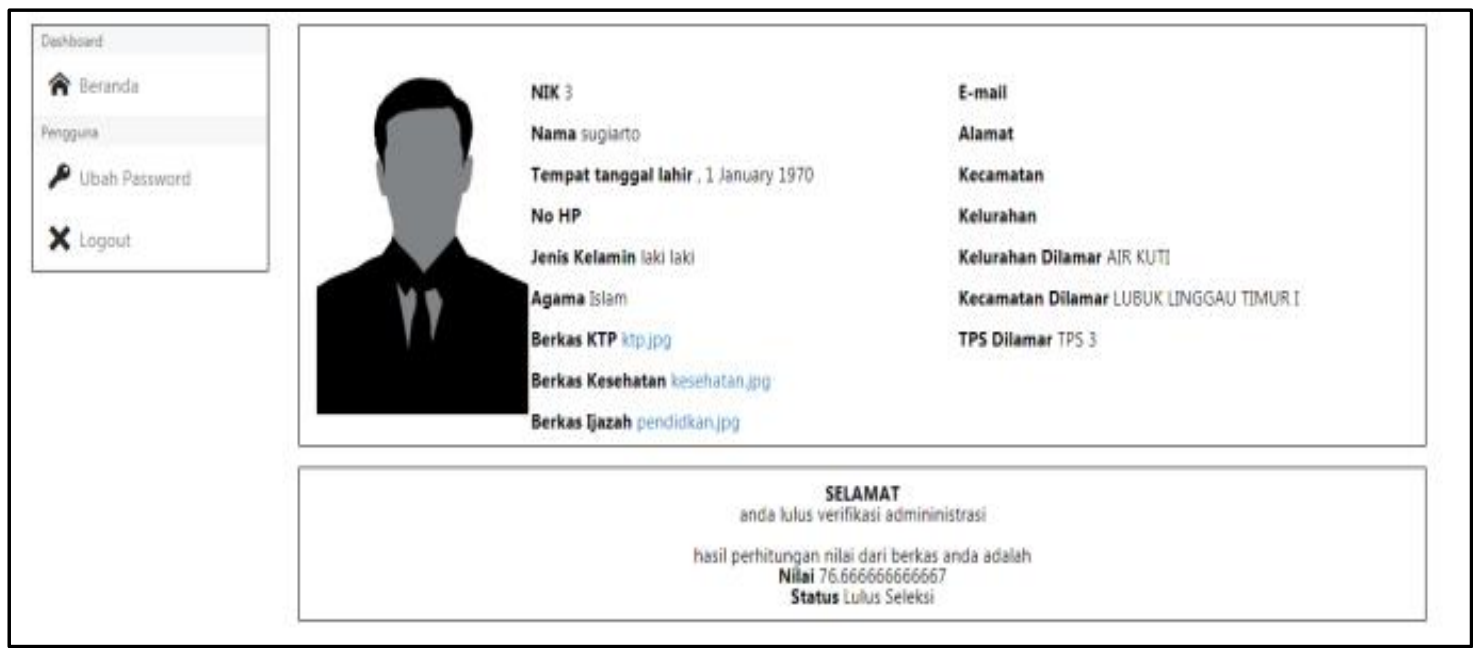

Gambar 7. Halaman Verifikasi Berkas Pendaftaran 
Gambar 7 merupakan halaman hasil verifikasi berkas yang dapat diketahui oleh pendaftar tentang informasi kelulusan administrasi berkas yang telah diperiksa oleh panitia rekrutmen anggota KPPS Pemilu Kota Lubuklinggau.

\begin{tabular}{|l||}
\hline Perangkingan \\
Kecamatan \\
\hline LUBUK LINGGAU TIMUR I \\
Kelurahan \\
WATERVANG \\
TPS \\
Pilih TPS \\
\hline Tambah \\
\hline
\end{tabular}

Gambar 8. Proses Seleksi/Perangkingan

Gambar 8 merupakan halaman proses seleksi/perangkingan yang dilakukan oleh panitia PPS dalam proses penilaian terhadap pendaftar anggota KPPS yang telah dinyatakan lulus administrasi berkas yang telah ditetapkan

\begin{tabular}{|c|c|c|c|c|c|c|c|}
\hline Not & Altemotit & Pendiditan & Keschotan & Domiall & Umur & Hasil & Keterangan \\
\hline - & $\operatorname{scos} x$ & 0.2 & 0.15 & 0.25 & 0.2 & - & - \\
\hline , & heang & 10 & 21 & 19 & $x$ & of & Luan Strivetio \\
\hline 2 & $\mathrm{Rom}$ & 13 & as & $z$ & 20 & $9 s$ & Luves Steteci \\
\hline 3 & Septy & 10 & is & 13 & 12 & $n$ & Luva Stloct: \\
\hline 1 & 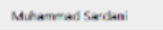 & 10 & 21 & $\%$ & 12 & sot & Iuans Striescie \\
\hline s & Mrsume & 20 & ars & 2 & 12 & ests & Lưus Stlecis \\
\hline 6 & Seratul & 10 & is & 625 & s & 3625 & Theak tuts \\
\hline ? & 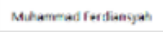 & 15 & 21 & 19 & 12 & bs & Tisate tubs \\
\hline - & Sumsndi & $=$ & 35 & 2 & 12 & $n$ & Luws Stecci \\
\hline ? & Limas abren & $=$ & 21 & 13 & 12 & 93 & Thear tuls \\
\hline 1n & reike volderdat & so & 35 & 26 & 12 & 2 & Lün Solvecit \\
\hline$" 1$ & Risam:o & 15 & 21 & 2 & 20 & 81 & Lưus Stlecis \\
\hline 12 & 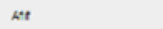 & 20 & s.s & 19 & 12 & 5375 & Theak tuls \\
\hline 13 & Redist & 10 & 21 & 26 & $x$ & 76 & Luans sortescici \\
\hline 14 & woives & 10 & 21 & 12 & 12 & 30 & Ticak tuta \\
\hline 13 & Pan & 10 & 13 & 625 & 3 & 3625 & neak tuta \\
\hline 16 & Iantego & 10 & 21 & 15 & $\mathrm{~s}$ & 51 & Tisat tubs \\
\hline 17 & sumseri & : & $3 s$ & 2 & 12 & $\pi$ & Luvos Stlecis \\
\hline 18 & Mastor & 13 & is & $2 s$ & 12 & 87 & Luan Salect \\
\hline 19 & tohin gin & 20 & 21 & 26 & 12 & $7 \mathrm{a}$ & Luans Sotriecti \\
\hline 20 & Perts & 10 & 35 & 025 & 5 & 3625 & Ticak tuta \\
\hline 21 & Monba & 20 & is & 6.25 & 12 & 7325 & Laut Stlects \\
\hline$n$ & Strasche & 10 & 21 & $\%$ & 12 & so & Luans Striesti \\
\hline 23 & lepi hrovn & 10 & 21 & 12 & 20 & 66 & Luva Stlecis \\
\hline
\end{tabular}

Gambar 9. Halaman Hasil Seleksi Anggota KPPS Pemilu Kelurahan Watervang

Gambar 9 merupakan informasi hasil seleksi yang diperoleh pada sistem dengan menerapkan metode SMART menghasilkan nilai rekomendasi penetapan anggota KPPS di Kelurahan Watervang yang terdiri dari 10 TPS. Dimana berdasarkan hasil perhitungan pada sistem dari 50 anggota KPPS yang diseleksi dengan kriteria/persyaratan yang telah ditetapkan diperoleh hasil yaitu 12 orang dinyatakan tidak lulus seleksi dan 38 orang dinyatakan lulus seleksi

\section{Pengujian Sistem}

Tahapan ini dilakukan melalui proses dokumentasi pengujian dengan menggunakan teknik blackbox testing seperti pada tabel 6 dan 7 Berdasarkan hasil pengujian terhadap semua fungsi pada interface yang ada pada sistem dapat berfungsi dengan baik. 
Tabel 6. Pengujian Fungsional PendaftaranCalon Anggota KPPS

\begin{tabular}{|c|c|c|c|}
\hline No & Skenario Pengujian & Hasil yang diharapkan & Kesimpulan \\
\hline 1 & $\begin{array}{l}\text { Mengisi biodata } \\
\text { pendaftar (field tidak } \\
\text { boleh kosong) lalu klik } \\
\text { tombol daftar }\end{array}$ & $\begin{array}{l}\text { Sistem akan menyimpan data } \\
\text { yang telah ditambahkan dan } \\
\text { akan memberikan informasi } \\
\text { username dan password } \\
\text { pendaftaran }\end{array}$ & Berhasil \\
\hline 2 & $\begin{array}{l}\text { Mengisi } \\
\text { Nama pengguna dan } \\
\text { Kata sandi } \\
\text { kemudian klik tombol } \\
\text { login }\end{array}$ & $\begin{array}{l}\text { sistem menerima } \\
\text { akses login dan } \\
\text { masuk ke halaman } \\
\text { pendaftar/calon } \\
\text { KPPS. }\end{array}$ & Berhasil \\
\hline 3 & $\begin{array}{l}\text { Mengupload data berkas } \\
\text { sesuai dengan format } \\
\text { yaitu pdf. Kemudian } \\
\text { mengklik tombol simpan }\end{array}$ & $\begin{array}{l}\text { Sistem menerima data dan } \\
\text { menyimpan data }\end{array}$ & Berhasil \\
\hline
\end{tabular}

Tabel 7. Dokumentasi Hasil Pengujian Blackbox

\begin{tabular}{llll}
\hline No & Komponen Pengujian & Hasil Pengujian & Tidak \\
\cline { 3 - 3 } & & Berhasil & \\
\hline $\mathbf{1}$ & Fungsi Menu Pendaftran & $\checkmark$ \\
\hline $\mathbf{3}$ & Fungsi Menu Login & $\checkmark$ \\
\hline $\mathbf{4}$ & Fungsi menu upload berkas & $\checkmark$ \\
\hline $\mathbf{5}$ & Fungsi tambah data kriteria & $\checkmark$ \\
\hline $\mathbf{6}$ & Fungsi menu ubah data kriteria & $\checkmark$ \\
\hline $\mathbf{8}$ & Fungsi menu hapus data kriteria & $\checkmark$ \\
\hline $\mathbf{9}$ & Fungsi menu tambah data subkriteria & $\checkmark$ \\
\hline $\mathbf{1 0}$ & Fungsi menu hapus data subkriteria & $\checkmark$ \\
\hline $\mathbf{1 1}$ & Fungsi menu verifikasi berkas & $\checkmark$ \\
\hline $\mathbf{1 3}$ & Fungsi menu pencarian data & $\checkmark$ \\
\hline $\mathbf{1 4}$ & Fungsi menu detail alternatif & $\checkmark$ \\
\hline $\mathbf{1 5}$ & Fungsi menu perangkingan & $\checkmark$ \\
\hline $\mathbf{1 6}$ & Fungsi menu verifikasi berkas & $\checkmark$ \\
\hline
\end{tabular}

\section{Kesimpulan}

Adapun kesimpulan pada penelitian ini adalah telah dibangun sistem pendukung keputusan rekrutmen anggota KPPS Pemilu KPUD Kota Lubuklinggau yang dapat mengelolah proses pendaftaran, verifikasi dan seleksi anggota KPPS dan dapat memberikan rekomendasi penetapan anggota KPPS Pemilu disetiap kelurahan yang ada di Kota Lubuklinggau. Kemudian berdasarkan hasil pengujian sistem menggunakan blackbox testing dapat diketahui secara fungsi sistem dapat berfungsi dengan baik sesuai dengan kebutuhan pengguna.

Ucapan Terima Kasih

Diucapkan Terima Kasih Pada DRPM Direktorat Jenderal Penguatan Riset dan Pengembangan Kementerian Pendidikan dan Kebudayaan yang telah mendanai kegiatan Hibah Penelitian Dosen Pemula Tahun Pelaksanaan 2020. Serta STMIK Bina Nusantara Jaya Lubuklinggau dan KPU Kota Lubuklinggau yang telah berperan aktif pada penelitian ini. 


\section{Daftar Pustaka}

[1] Mardani, A. Jusoh, and E. K. Zavadskas, "Fuzzy multiple criteria decision-making techniques and applications-two decades review from 1994 to 2014," Expert Systems with Applications, vol. 42, pp. 4126-4148, 2015.

[2] N. Sesnika, D. Anreswawi, and R. Efendi, "Aplikasi Sistem PendukungKeputusan Pemilihan Gedung Serba Guna Di Kota BengkuluDengan Menggunakan Metode Smartberbasis Android," J. Rekursif, vol. 4, pp. 30-44, 2016.

[3] Pinem., A.P.R, "Komparasi Metode ELECTRE, SMART dan ARAS Dalam Penentuan Prioritas Renaksi Pasca Bencana Alam," Jurnal Resti, vol. 4, pp. 109-116, 2020.

[4] Y. Primadasa and H. Juliansa, "Penerapan Metode Vikor dalam Seleksi Penerimaan Bonus Pada Salesman Indihome," Digital Zone, vol. 10, pp. 33-43, 2019.

[5] R. Yanto, "Sistem Pendukung Keputusan Prioritas Investasi dalam upaya Peningkatan Kualitas Perguruan Tinggi," Jurnal. RESTI (Rekayasa Sist. dan Teknol. Informasi), vol. 3, pp. 211-216, 2017.

[6] V Amalia, D Syamsuar, L Atika, "Komparasi Metode WP SAW dan WASPAS Dalam Penentuan Penerima Beasiswa Penelusuran Minat dan Kemampuan," Jurnal Informatika, vol. 6, pp. 114-121, 2019.

[7] R. K. Mavi, M. Goh, and N. Zarbakhshnia, "Sustainable third-party reverse logistic provider selection with fuzzy SWARA and fuzzy MOORA in plastic industry," The International Journal of Advanced Manufacturing Technology, vol. 91, pp. 2401-2418, 2017.

[8] M. Safrizal, "Sistem Pendukung Keputusan Pemilihan Karyawan Teladan dengan Metode SMART ( Simple Multi Attribute Rating Technique )," J. coreIT, vol. 1, pp. 25-29, 2015.

[9] T. Magrisa, K. Diah, and K. Wardhani, "Implementasi Metode Smart pada Sistem Pendukung Keputusan Pemilihan Kegiatan Ekstrakurikuler untuk Siswa SMA," Inform. Mulawarman, vol. 13, pp. 49-55, 2018.

[10] Risawandi., Rahim., R, "Study of the Simple Multi-Attribute Rating Technique For Decision Support," International Journal of Scientific Research in Science and Technology, vol. 2, pp. 491-494, 2016.

[11] M. Safriza,Suryanto, "Sistem Pendukung Keputusan Pemilihan Karyawan Teladan denganMetode SMART ( Simple Multi Attribute Rating Technique," CoreIT, vol. 1, p. 2529, 2015.

[12] Saputra., A.R., Mawartika, "Sistem Pendukung Keputusan Dalam Memilih Lokasi Perumahan Dengan Metode Simple Multi Attribute RatingTechnique," Cogito Smart Journal, vol. 5, pp. 35-44, 2019.

[13] Amalia., V., Yanto., R., Hamidani., S, "Komparasi Metode Saw Dan Smart Penerima Kartu Indonesia Pintar (KIP)," Jurnal Teknologi Informasi Mura, vol. 12, pp. 90-98, 2020.

[14] Astari., S.R., Umar., R., Sunardi, "Perbandingan Metode Profile Matching Dengan Metode SMART UntukSeleksi Asisten Laboratorium," Jurnal Resti, vol. 4, pp. 311-318, 2020.

[15] Shalahudin, Rosa A.S, Rekayasa Perangkat Lunak Terstruktur dan Berorientasi Objek, Bandung: Informatika, 2013.

[16] Yusuf., F, "Uji Validitas dan Reliabilitas Instrumen Penelitian Kuantitatif," Jurnal Ilmiah Kependidikan, vol. 7, pp. 17-23, 2018.

\section{(i) (2)}

BY SA Digital Zone: Jurnal Teknologi Informasi dan Komunikasi is licensed under a_Creative Commons Attribution International (CC BY-SA 4.0) 